OCT 1.8 .1988

\title{
Braze Alloy Development for Zircaloy
}

\author{
A. H. Donovan \\ Date Published \\ May 1988 \\ Presented at \\ Department of Metallurgy \\ University of Utah \\ Salt Lake City, Utah
}

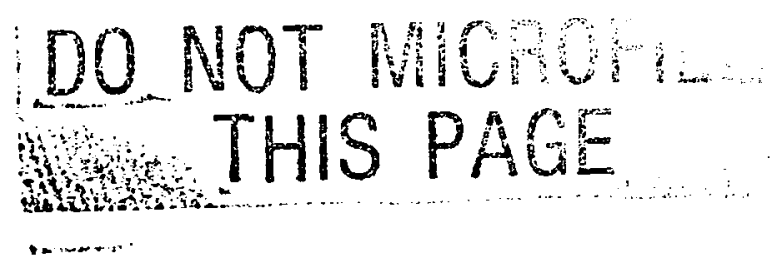

Prepared for the U.S. Department of Energy Assistant Secretary for Defense Programs

\section{We Westinghouse P.O. Box 1970 \\ Hanford Company Richland, Washington 99352}

Hanford Operations and Engineering Contractor for the

U.S. Department of Energy under Contract DE-AC06-87RL10930

Copyright License By acceptance of this article, the publisher and/or recipient acknowledges the U.S. Government's right to retain a nonexclusive, royalty-free license in and to any copyright covering this paper.

This document is PUBLICLY RELEASABLS $\frac{B \text { any Stobs }}{\text { Authorizing Official }}$
Date: $i v / 31 / 06$ 


\section{DISCLAIMER}

This report was prepared as an account of work sponsored by an agency of the United States Government. Neither the United States Government nor any agency Thereof, nor any of their employees, makes any warranty, express or implied, or assumes any legal liability or responsibility for the accuracy, completeness, or usefulness of any information, apparatus, product, or process disclosed, or represents that its use would not infringe privately owned rights. Reference herein to any specific commercial product, process, or service by trade name, trademark, manufacturer, or otherwise does not necessarily constitute or imply its endorsement, recommendation, or favoring by the United States Government or any agency thereof. The views and opinions of authors expressed herein do not necessarily state or reflect those of the United States Government or any agency thereof. 


\section{DISCLAIMER}

Portions of this document may be illegible in electronic image products. Images are produced from the best available original document. 


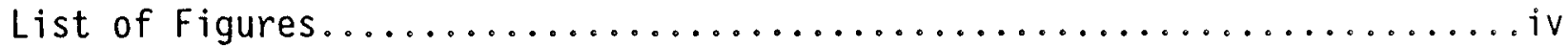

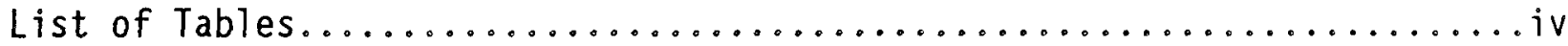

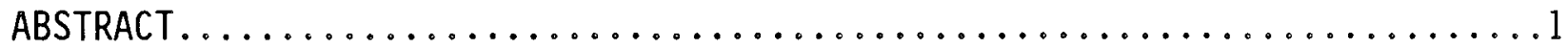

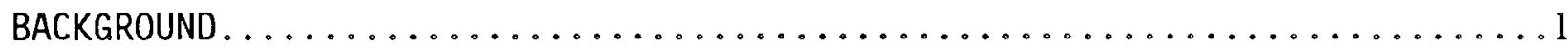

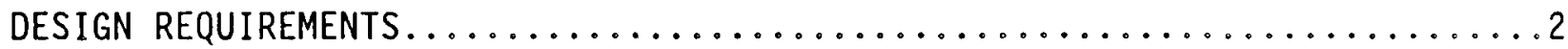

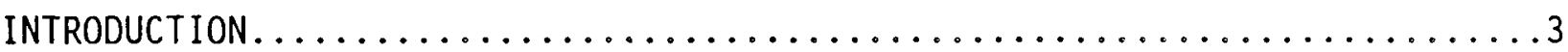

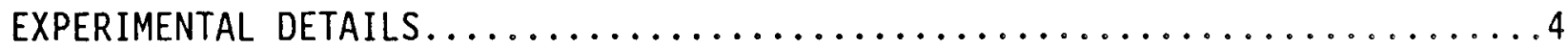

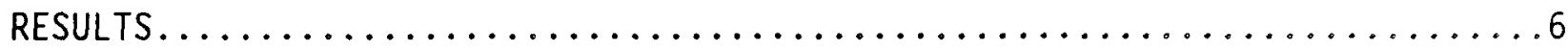

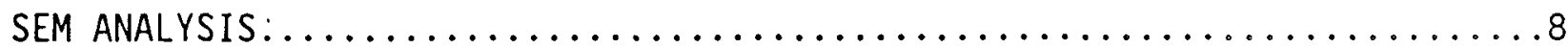

RECOMMENDATIONS FOR FUTURE WORK............................. 15

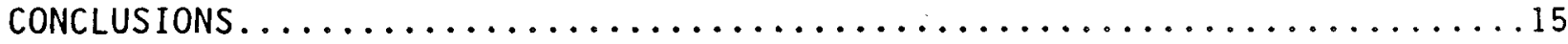

REFERENCES........................................

\section{DISCLAIMER}

This report was prepared as an account of work sponsored by an agency of the United States Government. Neither the United States Government nor any agency thereof, nor any of their employees, makes any warranty, express or implied, or assumes any legal liability or responsibility for the accuracy, completeness, or usefulness of any information, apparatus, product, or process disclosed, or represents that its use would not infringe privately owned rights. Reference herein to any specific commercial product, process, or service by trade name, trademark, manufacturer, or otherwise does not necessarily constitute or imply its endorsement, recommendation, or favoring by the United States Government or any agency thereof. The views and opinions of authors expressed herein do not necessarily state or reflect those of the United States Government or any agency thereof. 


\section{LIST OF FIGURES}

1. Dimensions of Prototype Driver Fuel Samples..................

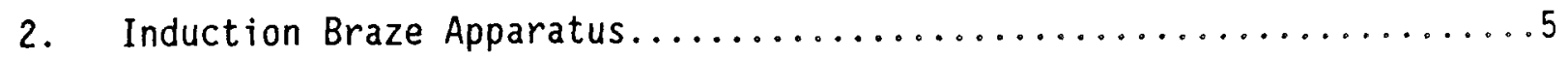

3. Metallography of Brazed End Closure $(7 X$ and $50 x) \ldots \ldots \ldots \ldots$

4. SEM Analysis of Braze Region $(100 x) \ldots \ldots \ldots \ldots \ldots \ldots \ldots$

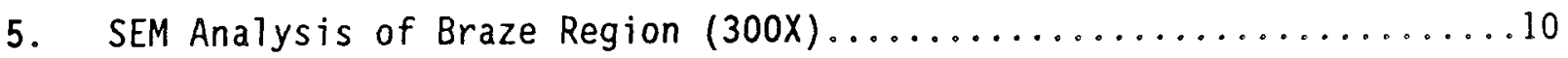

6. Nickel X-Ray Map of Area No. $2(300 x) \ldots \ldots \ldots \ldots \ldots \ldots \ldots \ldots$

7. Chromium $x$-Ray Map of Area No. $2(300 x) \ldots \ldots \ldots \ldots \ldots \ldots \ldots$

8. SEM Analysis of Braze Region $(1000 x) \ldots \ldots \ldots \ldots \ldots \ldots \ldots \ldots$

9. SEM Analysis of Braze Region (3000x) ...........................

\section{LIST OF TABLES}

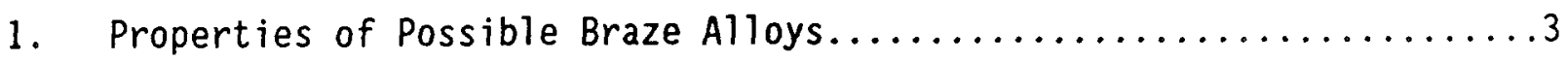

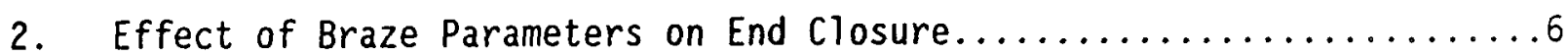

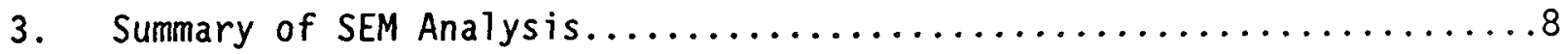


WHC-SA-0317-FP

BRAZE ALLOY DEVELOPMENT FOR ZIRCALOY

\section{ABSTRACT}

The purpose of this study was to find a suitable braze alloy to close the ends of a new fuel design for $N$ Reactor, the defense reactor at the Hanford site, Washington. An alloy composed of Zircaloy-2 +8 wt\% chromium +8 wt\% nickel $(\mathrm{Zr} 2-8 \mathrm{Cr}-8 \mathrm{Ni})$ was successfully used to obtain an acceptable joint with no voids. Suggestions for future work on end closure development for the new fuel are outlined. This alloy has potential use in any Zircaloy joining applications.

\section{BACKGROUND}

This work was performed in support of a program to develop a new fuel design for $\mathrm{N}$ Reactor. The components of the new fuel design discussed in this report are the metallic core, the lateral Zircaloy-2 cladding, and the end closure. The core and the cladding are extruded together to form the tubular fuel. The extrusion is then cut to the desired lengths. The cut ends of the fuel leave the core metal exposed. The ends of the fuel must be closed to protect the core from the corrosive effects of the reactor coolant. This is accomplished by removing about $0.5 \mathrm{in}$. of the core material from the ends of the fuel by machining. An end cap, basically a ring of Zircaloy-2, fits into the recess formed by the machining process. The Zircaloy-2 end cap is then joined to the Zircaloy-2 cladding and the core material to form a leaktight closure on each end of the fuel. The brazed closure method has proven to be reliable and offers superior resistance to impact and low failure frequency. Brazing is a joining process similar to soldering in which only the filler metal is melted at a temperature below the melting point of the metals to be joined. 


\section{DESIGN REQUIREMENTS}

The end closure must be leaktight, corrosion resistant, provide good heat transfer, and be sufficiently strong to withstand the mechanical and thermal loads during handling and irradiation. The brazed closure method has proven to be reliable and offers superior resistance to impact and low failure frequency. The braze material currently used for this application is $\operatorname{Zr} 2-5 \mathrm{Be}$.

Because of the toxicity of beryllium, and the associated costs of handling a toxic material, an investigation was made to determine if any additional alloys appeared promising. Although the melting point of the core material has not been established at this time, it will be assumed for the purposes of this paper to be $1600^{\circ} \mathrm{C}$ or greater.

The braze material that will satisfactorily meet the requirements of this fuel design should have most of the following attributes:

1. Brazing temperature less than $1600^{\circ} \mathrm{C}$, preferably less than $800^{\circ} \mathrm{C}$.

2. Low neutron capture.

3. Good wetting and flow properties.

4. Low vapor pressure at the brazing temperature to avoid vaporization during the brazing operation.

5. Good corrosion resistance.

6. Fair ductility to form a tough bond with the Zircaloy and to form into sheet or wire for placement in the braze joint. 
WHC-SA-0317-FP

\section{INTRODUCTION}

Zirconium-base brazing alloys are attractive for several reasons: they have a low neutron cross section, the amount of foreign material added to the braze is kept at a minimum, and several of the zirconium-base alloys are quite corrosion-resistant. Several metals reduce the melting point of zirconium by the formation of a eutectic. Some of these metals are beryllium, copper, silver, iron, chromium, manganese, and nickel.

Zirconium or Zircaloy can be brazed without a flux if it is heated to $690^{\circ} \mathrm{C}$. At this temperature the metal dissolves the surface oxide film allowing wetting by the molten brazing alloy. The brazing operation must be performed in an inert gas or vacuum because of the reactivity of zirconium with oxygen at the required brazing temperatures. All of the present Zircaloy brazing alloys require temperatures in excess of $800^{\circ} \mathrm{C}$. Heating Zircaloy through the alpha-plus-beta range $\left(830^{\circ}\right.$ to $\left.975^{\circ} \mathrm{C}\right)$ increases the probability of poorer corrosion resistance.

Four alloys were identified through a literature search as possible braze materials for joining Zircaloy. They are listed in Table 1 with properties desired for this application.

Table 1. Properties of Possible Braze Alloys.1,2

\begin{tabular}{lcccccc}
\hline $\begin{array}{l}\text { Braze } \\
\text { Alloy }\end{array}$ & $\begin{array}{l}\text { Braze } \\
\text { Temp. } \\
\left({ }^{\circ} \mathrm{C}\right)\end{array}$ & $\begin{array}{l}\text { Wetting } \\
\text { and Flow }\end{array}$ & $\begin{array}{l}\text { Corrosion } \\
\text { Resistance }\end{array}$ & $\begin{array}{c}\text { Tensile } \\
\text { Strength } \\
\text { (psi) }\end{array}$ & $\begin{array}{c}\text { Ductility } \\
\text { Dctivation* } \\
\text { (MeV/s) }\end{array}$ \\
\hline Zr-50Ag & 1420 & excellent & excellent & 39,425 & good & 2116 \\
$Z r-29 \mathrm{Mn}$ & 1280 & good & excellent & 33,990 & good & 1.1 \\
Zr-12Fe & 1150 & good & excellent & 27,480 & poor & 1.7 \\
Zr2-8Cr-8Ni & 950 & excellent & good & no data & poor & 1.9 \\
* Provided by Warren Wittekind, Westinghouse Hanford Company. &
\end{tabular}

The $\mathrm{Zr}-50 \mathrm{Ag}$ alloy was eliminated as a braze material because of its high nuclear activation energy. $Z r-12 F e$ was reported to be satisfactory on the basis of corrosion resistance and brazing characteristics but gave variable results from the standpoint of mechanical strength. $2 \mathrm{r} 2-8 \mathrm{Cr}-8 \mathrm{Ni}$ was chosen for initial testing because of its low braze temperature. 


\section{EXPERIMENTAL DETAILS}

The $\mathrm{Zr} 2-8 \mathrm{Cr}-8 \mathrm{Ni}$ alloy, developed at Argonne National Laboratory, was named "ANL \#11" and was patented in 1960.3 Previous work reported that this alloy is molten at $950^{\circ} \mathrm{C}$ and wets nearly all metals and ceramics at that temperature. Flow characteristics are excellent. Although the corrosion resistance has not been thoroughly tested, specimens were tested by ANL for three weeks at $400^{\circ} \mathrm{C}$ and $1500 \mathrm{psi}$ (steam) with no evidence of corrosion.

The worst feature is brittleness, which makes fabrication of the braze ring difficult. The Zr2-5Be braze ring used on the current fuel design is also very brittle and must be fabricated by casting the alloy in a cylinder and cutting thin slices. Ideally, the braze alloy would be rolled to a thickness of about 0.1 in., and the braze ring would be stamped from the alloy sheet. It has been reported that strips of about 0.010 in. have been made by hot rolling in a stainless steel sheath.?

The $2 r 2-8 \mathrm{Cr}-8 \mathrm{Ni}$ alloy is not available commercially so it was fabricated onsite. Pieces of Zircaloy, nickel wire, and chrome flakes were arc-melted together in the proper amounts to make the alloy. The button that was formed was flipped several times to improve the homogeneity of the alloy. At this stage of the test program it was not practical to attempt development of a fabrication process to produce a braze ring from the alloy, so for testing purposes, the button was cut into small chunks (approximately $0.3 \times 0.3 \times 0.1$ in.).

Four prototype new fuel samples and end caps were machined from Zr2 tube stock with the dimensions shown in Figure 1. Full-length fuel samples were not needed because only the end of the fuel is affected by the braze cycle. The end cap fits in the recess that is machined in the end of the fuel. The braze material was placed on top of the end cap, and the sample was heated in the induction braze apparatus shown in Figure 2.

The braze operation was performed in a vacuum chamber by inductionheating the end of the prototype fuel element, melting the braze alloy, pressurizing the chamber with argon to force the molten braze down around the end cap, and allowing the brazed element to cool in argon. 


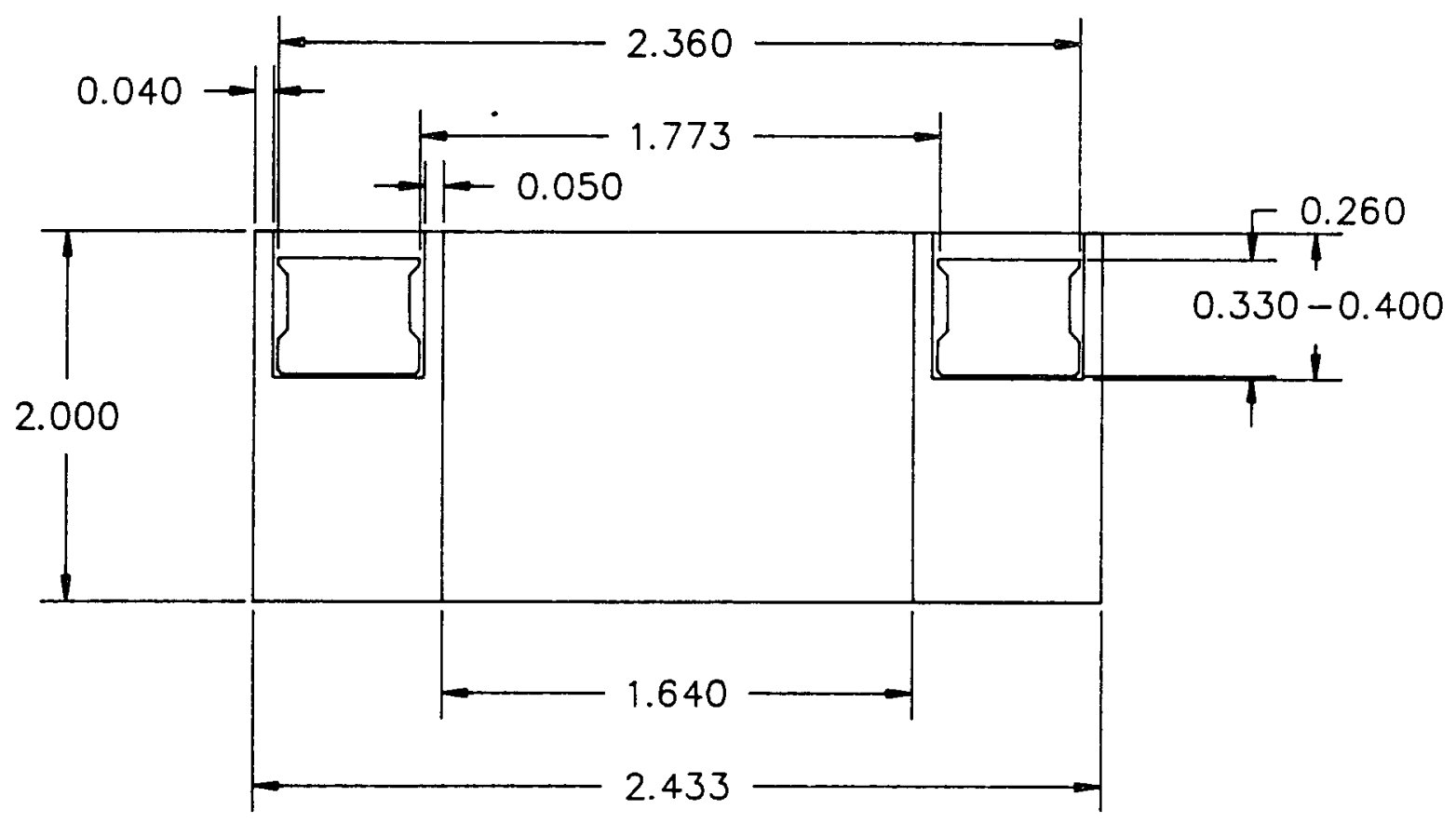

Figure 1. Dimensions of Prototype Fuel Samples.

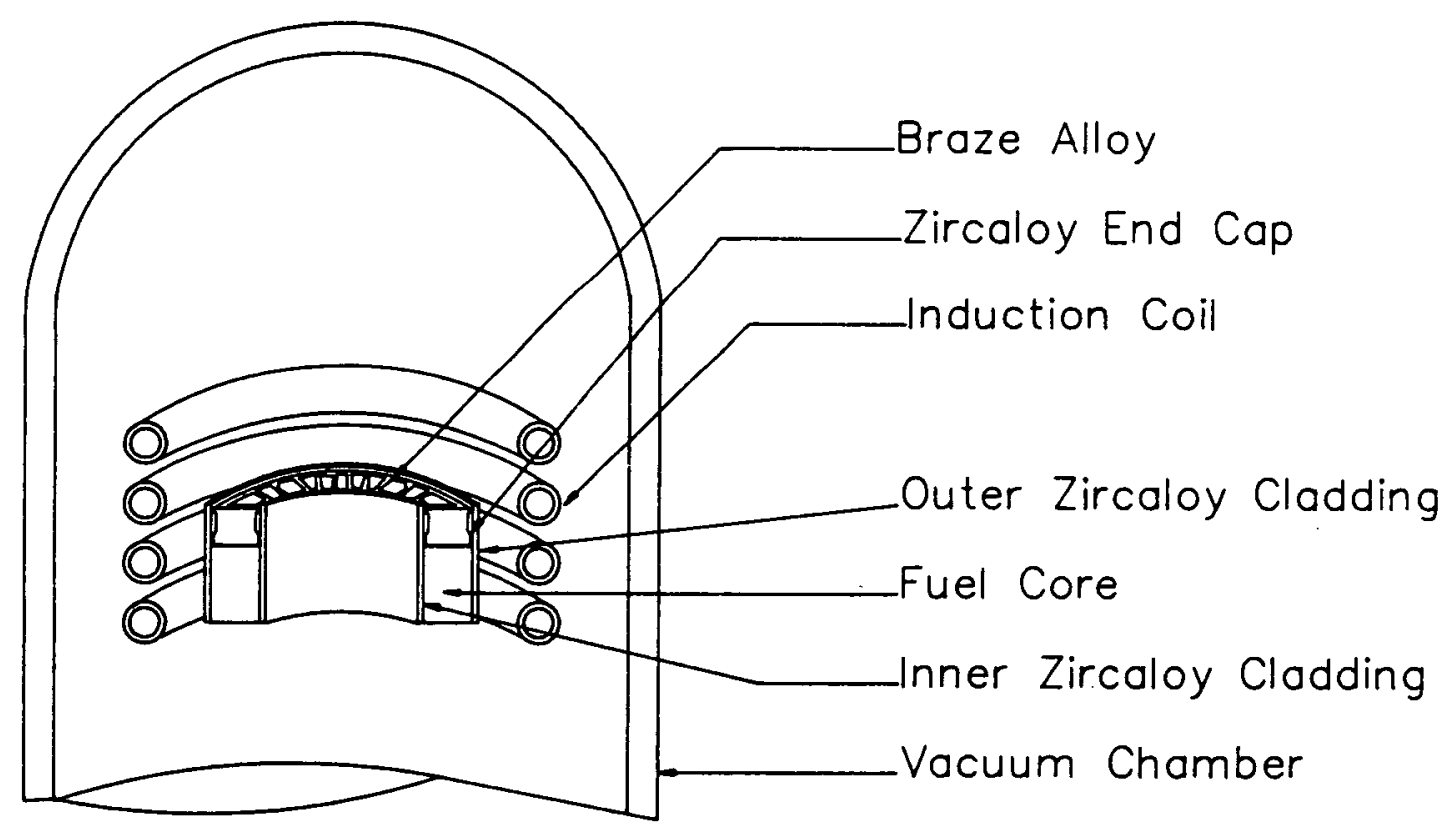

Figure 2. Induction Braze Apparatus. 


\section{$\underline{\text { RESULTS }}$}

The four fuel samples were induction-brazed using different braze conditions, as shown in Table 2. The brazed samples were sectioned and examined after each test.

Table 2. Effect of Braze Parameters on End Closure.

\begin{tabular}{cccccc}
\hline $\begin{array}{l}\text { Sample } \\
\text { Number }\end{array}$ & $\begin{array}{l}\text { Braze } \\
\text { Amount } \\
(\mathrm{g})\end{array}$ & $\begin{array}{l}\text { Recess } \\
\text { Depth } \\
(\mathrm{in} .)\end{array}$ & $\begin{array}{l}\text { Temp } \\
\left({ }^{\circ} \mathrm{C}\right)\end{array}$ & $\begin{array}{l}\text { Time } \\
(\mathrm{s})\end{array}$ & Closure \\
\hline 1 & 8.8 & 0.326 & 1090 & 110 & Targe voids \\
2 & 15.6 & 0.330 & 1125 & 170 & sma11 voids \\
3 & 16.5 & 0.396 & 1125 & 170 & no voids \\
\hline 4 & 17.0 & 0.400 & 1130 & 170 & no voids \\
\hline
\end{tabular}

The first braze test was performed using only $8.8 \mathrm{~g}$ of the alloy because of concern that some spillover of the alloy could occur. After the first test was run, it was determined that this was not a problem, so the amount of braze alloy was increased.

Some alloy pieces sat partially above the edge of the machined end recess on the first two tests. During the braze cycle, it was observed that these pieces took much longer to heat up. This phenomenon was thought to be due to the greater heat loss of those alloy pieces positioned above the wall of the tube. The depth of the machined recess in the $\mathrm{Zr}$ tube was increased to $0.4 \mathrm{in}$. for the subsequent tests.

No voids were observed in the last two tests, but the surface of the alloy after brazing showed that a few alloy pieces had not melted completely. The optimum braze temperature observed was somewhat higher than expected.

A cross section of the fourth braze test is shown in Figure 3 . The metallography of this sample indicates that no voids occurred and that an adequate braze was obtained. 

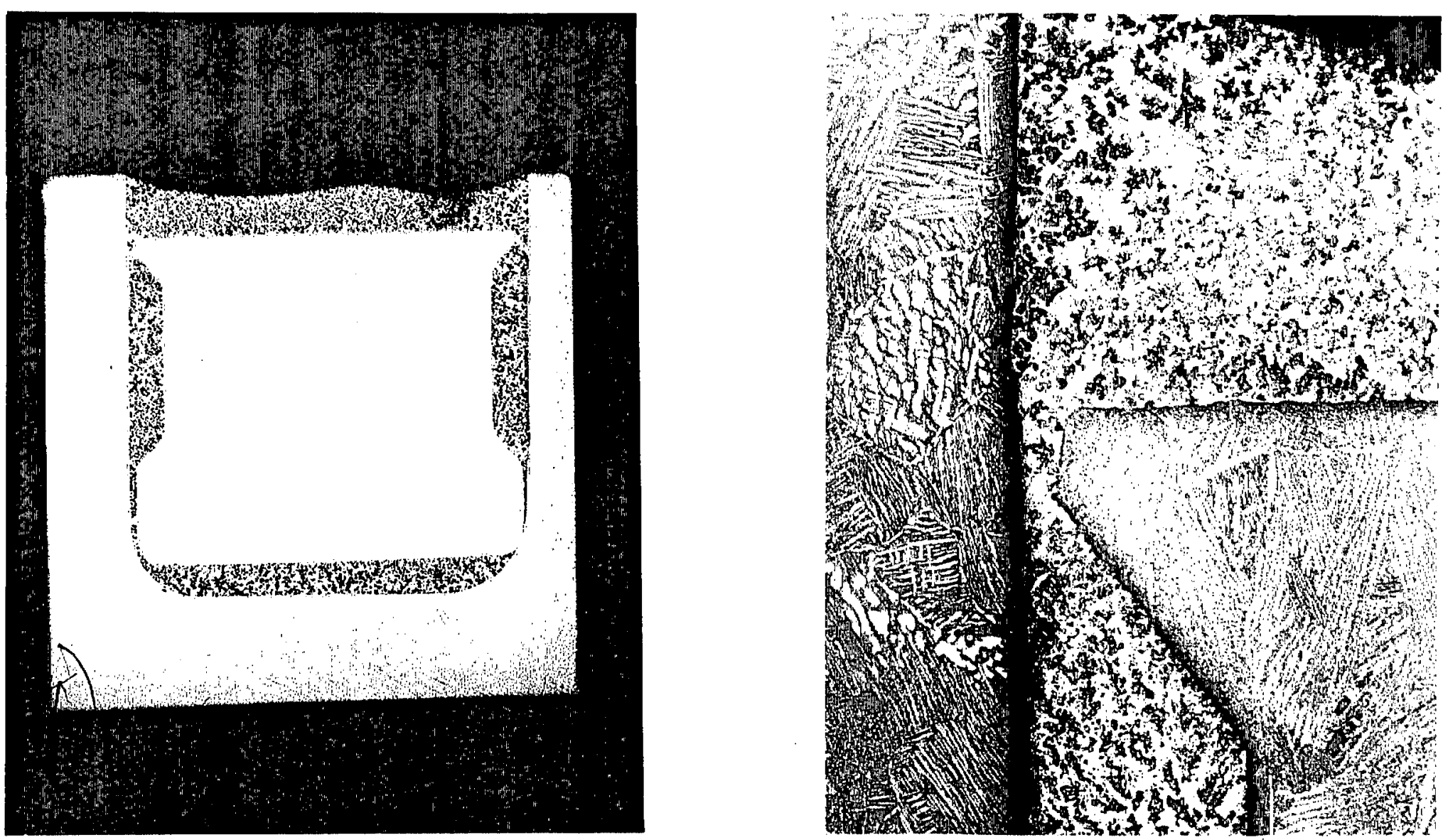

Figure 3. Metallography of Brazed End Closure ( $7 X \& 50 X)$. 


\section{SEM ANALYSIS}

The Scanning Electron Microscope (SEM) was used to examine the brazed joint of the final specimen. The braze alloy was analyzed using $x$-ray diffraction to determine the actual wt\% of nickel and chromium in different regions of the end closure. The braze region between the end cap and the cladding was examined at $100 \mathrm{X}$ magnification and analyzed in the three areas shown in Figure 4. Area No. 2 was examined at $300 x$ in Figure 5 , and an analysis of the $\mathrm{Zr} 2$ end cap was performed as a check since its composition is known.

The dark area of Figure 5 was analyzed and was found to have about twice the chromium as the areas in Figure 4. X-ray mapping of the area was performed, highlighting the nickel in Figure 6 and the chromium in Figure 7 . Figure 8 shows a region near the end cap at a magnification of $1000 x$. This area was examined further at $3000 x$ magnification, and $x$-ray analysis was performed in the areas shown in Figure 9. A summary of the x-ray analys is results is given in Table 3 .

Table 3. Summary of SEM Analys is.

\begin{tabular}{llrrr}
\hline $\begin{array}{l}\text { Area } \\
\text { No. }\end{array}$ & $\begin{array}{l}\text { Location } \\
\text { Description }\end{array}$ & Zr & Normalized Wt\% \\
& & & $\mathrm{Ni}$ \\
\hline & Zr2 End Cap & 98.5 & 0.3 & 0.1 \\
2 & Braze Region & 84.8 & 7.0 & 7.0 \\
3 & Braze Region & 86.5 & 6.9 & 5.5 \\
4 & Braze Region & 84.8 & 7.5 & 6.5 \\
5 & Nicke7 Grain & 78.7 & 19.7 & 1.6 \\
6 & Near Zr2 End Cap & 97.2 & 0.4 & 0.2 \\
7 & Point Scan & 85.4 & 6.6 & 5.9 \\
8 & Chromium Area & 83.0 & 1.3 & 14.7 \\
\hline
\end{tabular}

Photographs taken during the SEM examination illustrate several interesting phenomena in the braze alloy. An analysis of Area No. 6 near the Zr2 end cap, shown in Figure 8 , is very low in both nickel and chromium. This grain, shown fully in Figure 9, is probably a part of the Zr2 end cap that has moved into the braze region.

Visible segregation of chromium and nickel is apparent in the braze alloy. From the x-ray mapping of chromium and nickel, it was concluded that the dark areas in Figures 4 and 5 are higher in chromium and most of the lighter colored background is higher in nickel. 


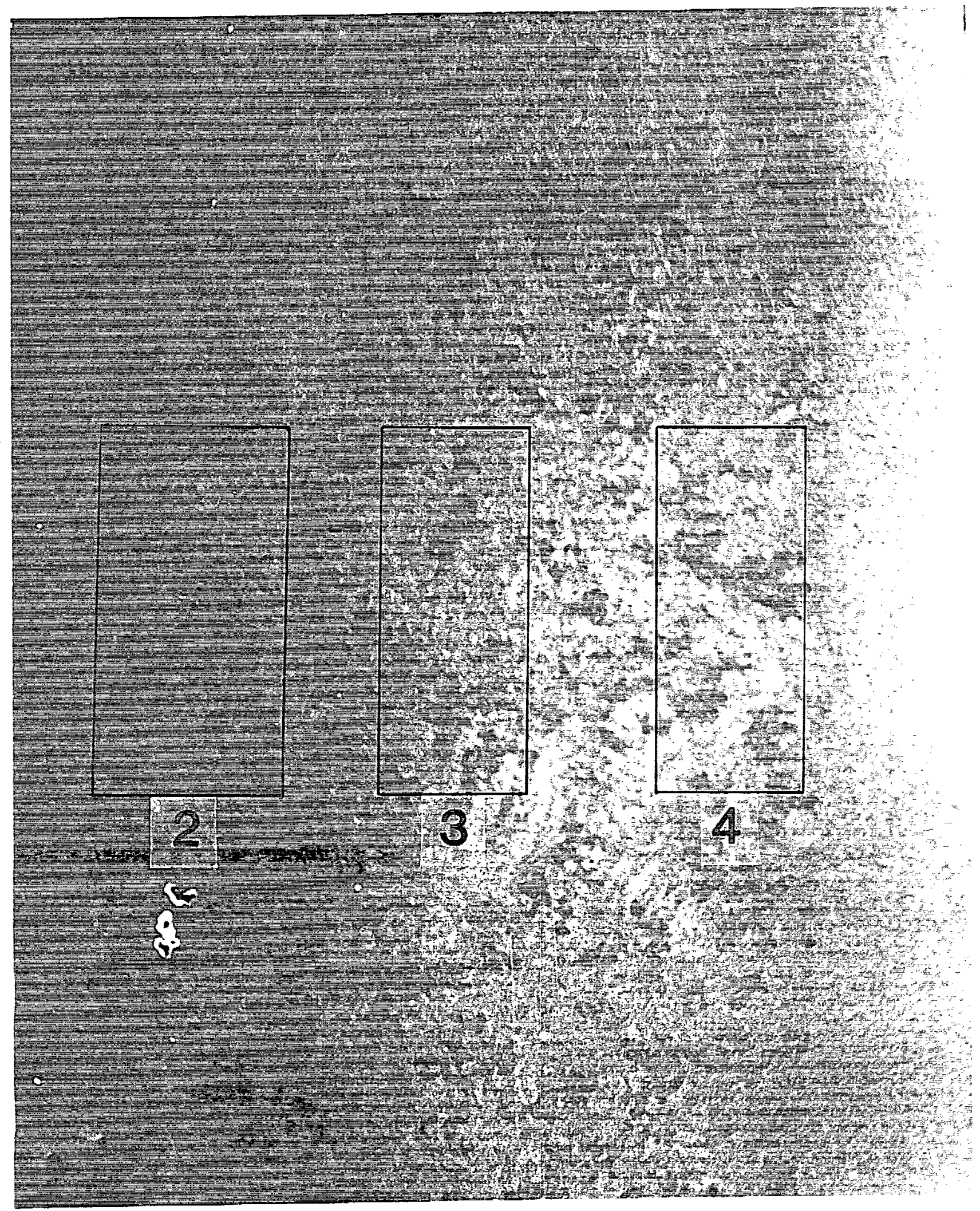

Figure 4. SEM Analys is of Braze Region (100X). 


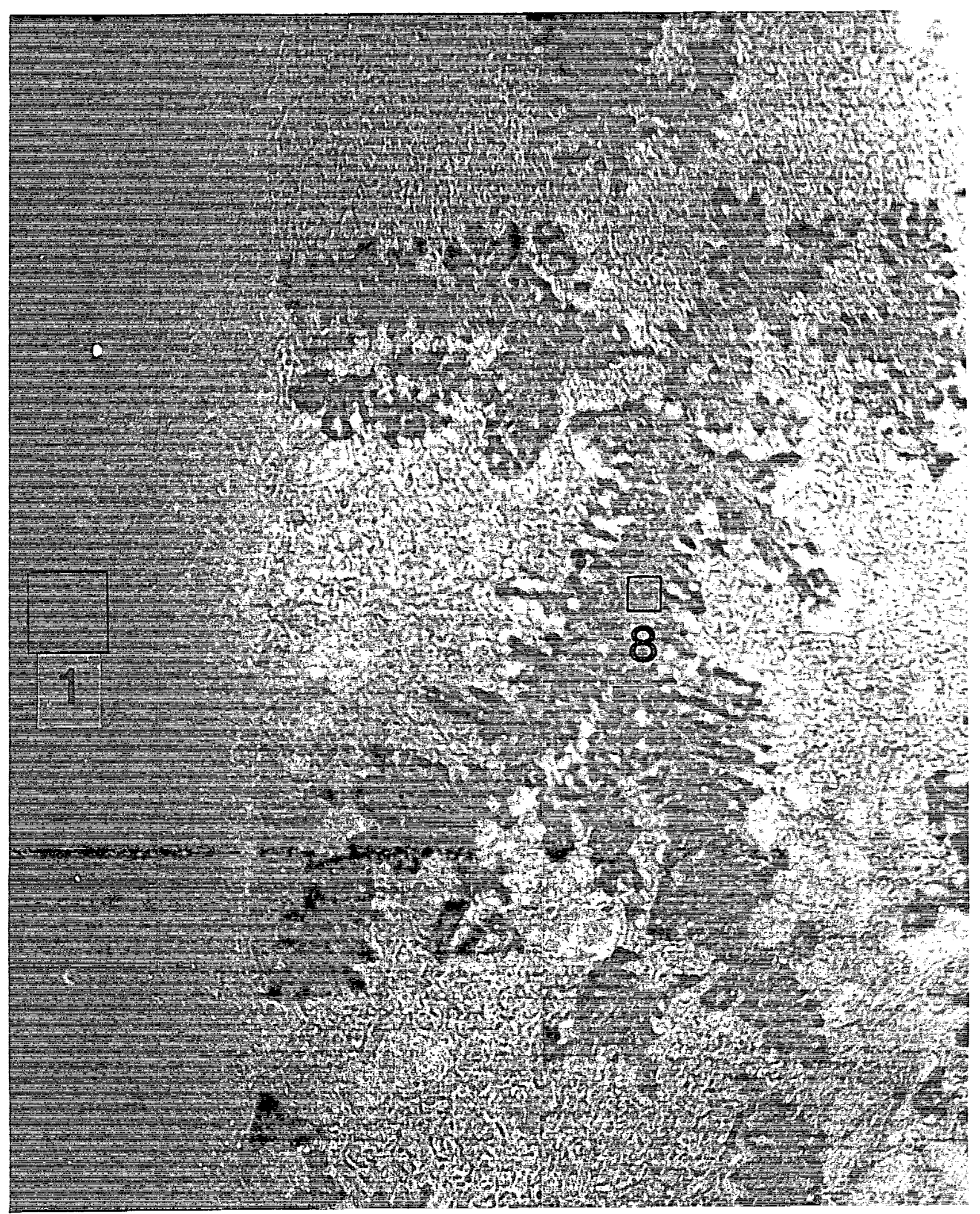

Figure 5. SEM Analysis of Braze Region (300X). 


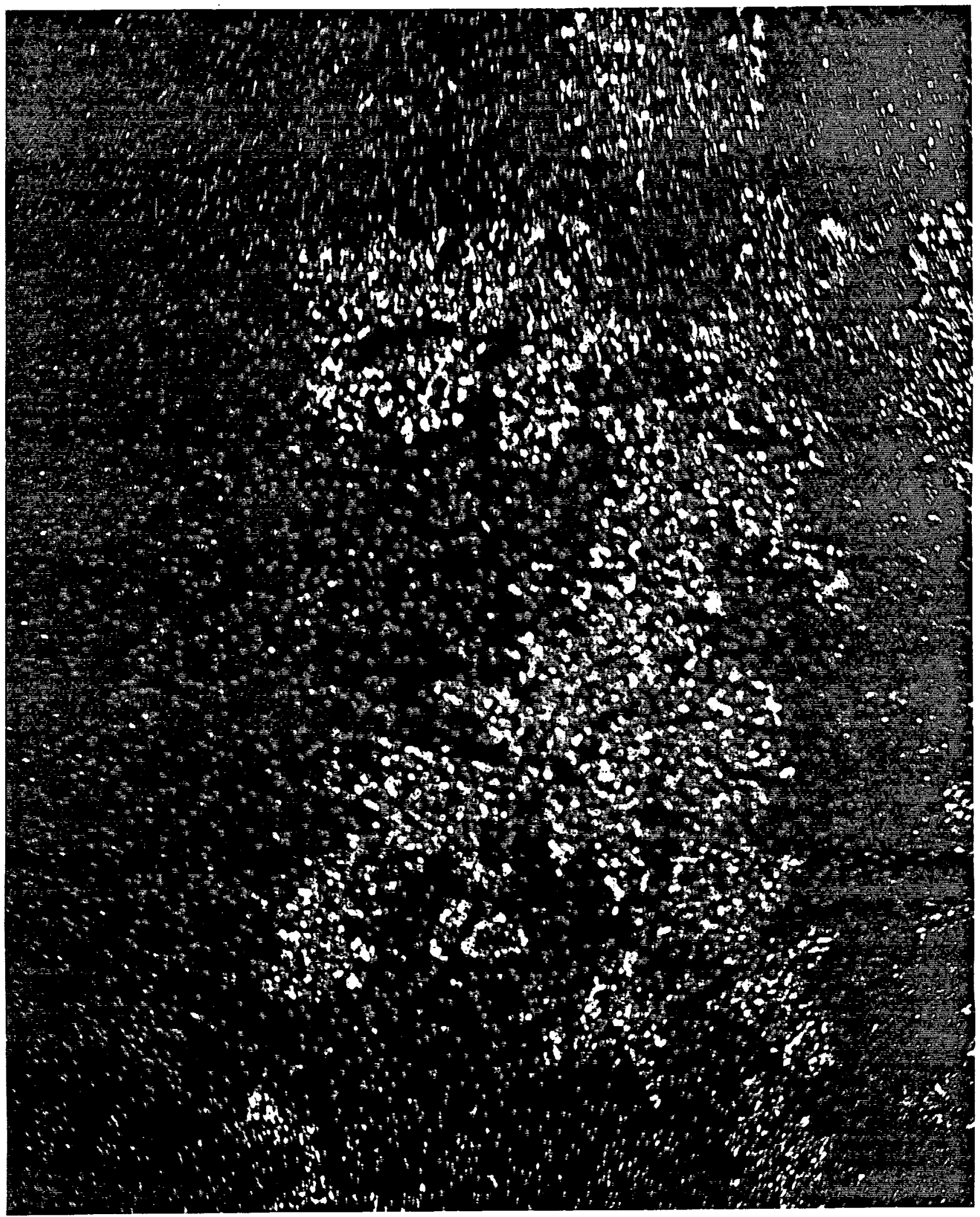

Figure 6. Nickel X-Ray Map of Area No. 2 (300X). 


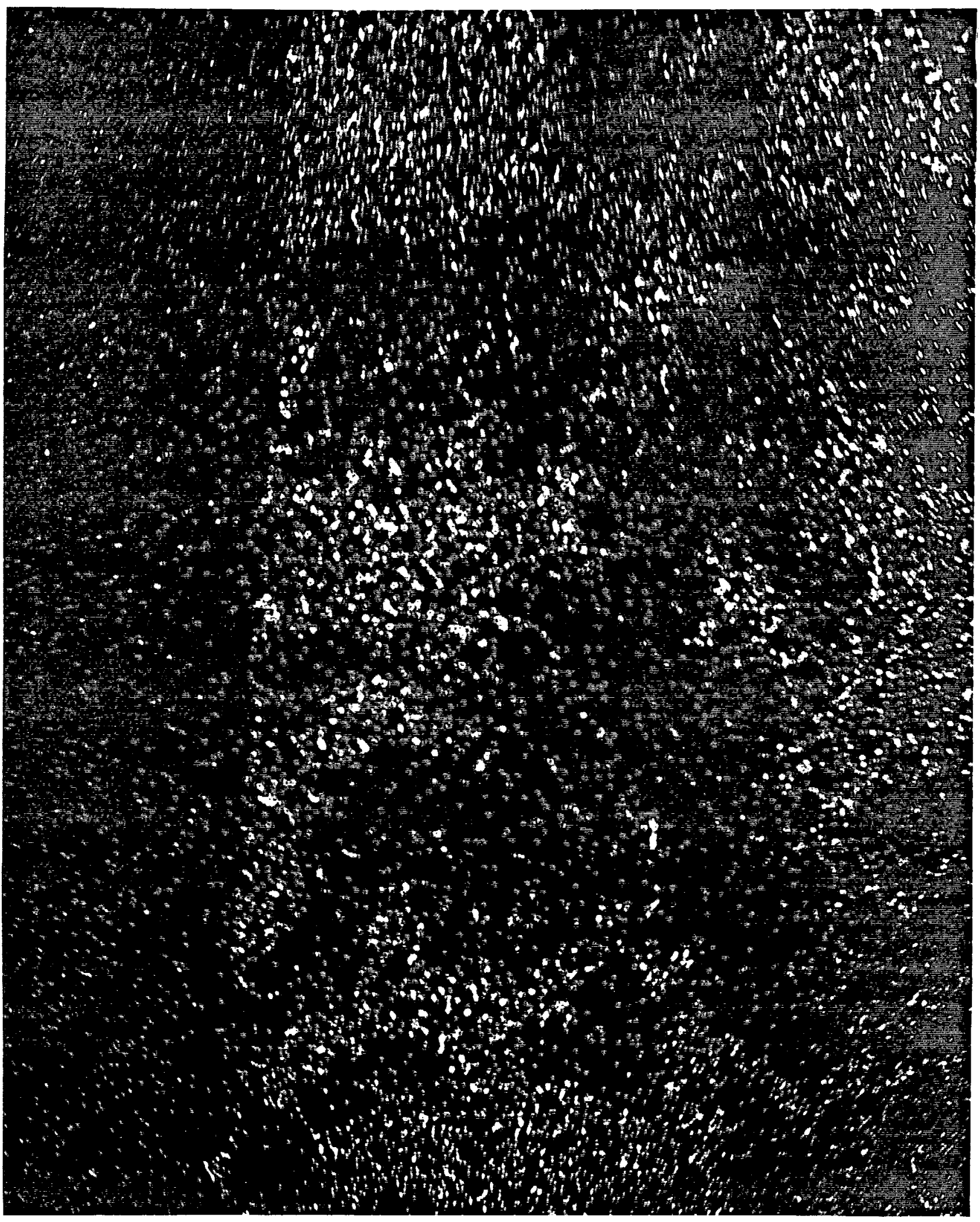

Figure 7. Chromium X-Ray Map of Area No. 2 (300X). 


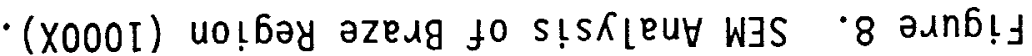

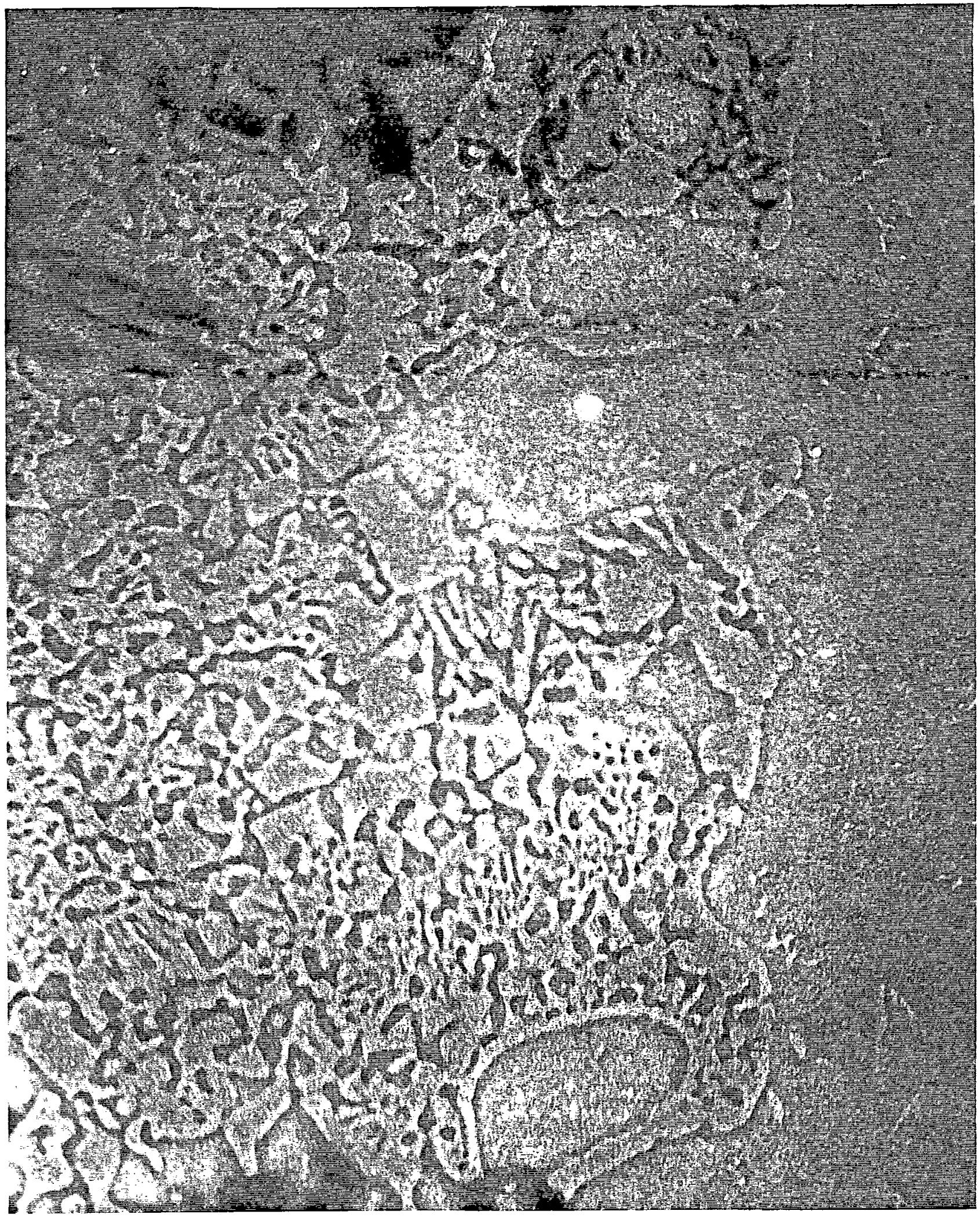




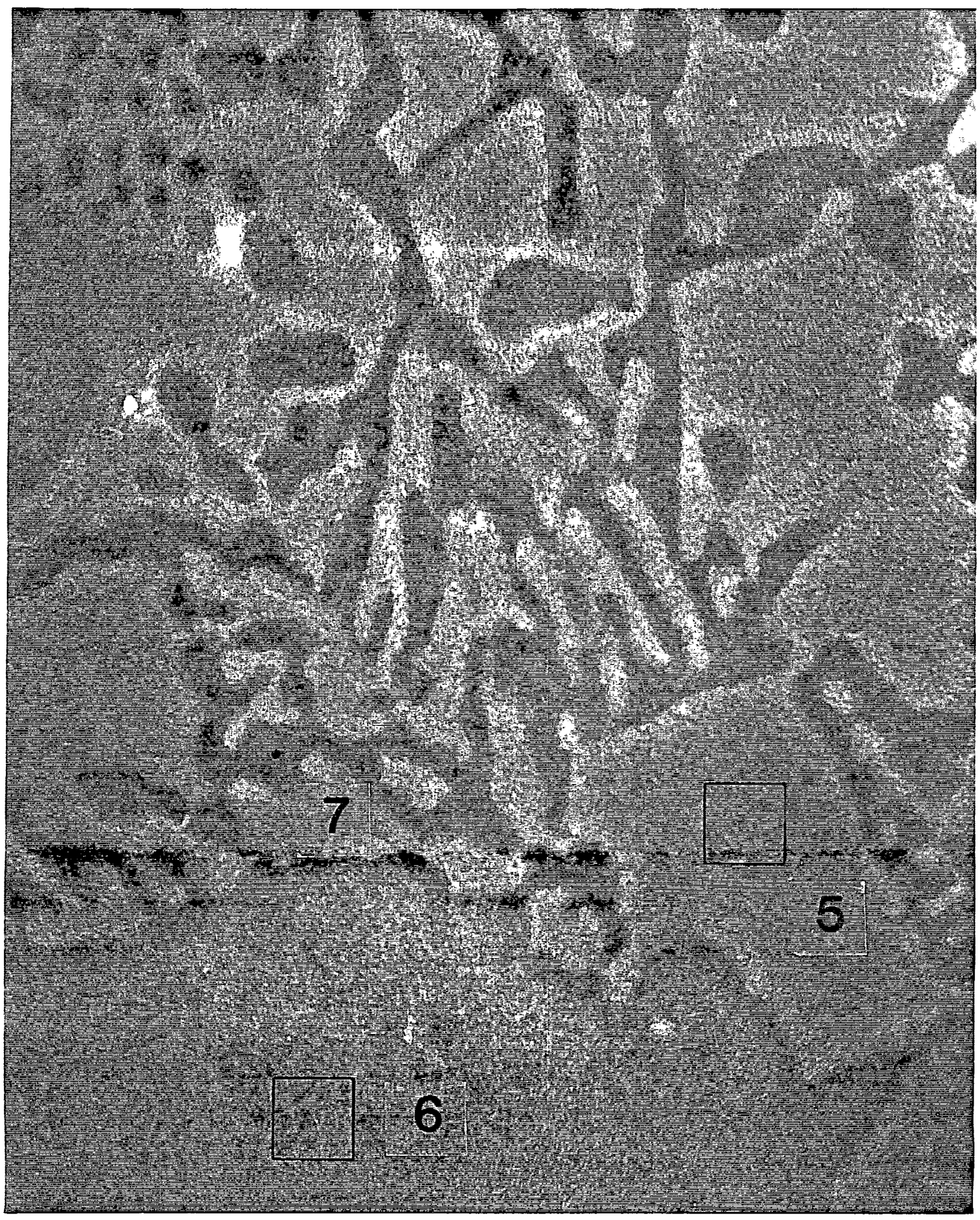

Figure 9. SEM Analysis of Braze Region (3000X). 


\section{RECOMMENDATIONS FOR FUTURE WORK}

The $\mathrm{Zr} 2-8 \mathrm{Cr}-8 \mathrm{Ni}$ alloy has great potential for use as the braze alloy for the new fuel, but further testing must be performed. Suggestions for future work on this alloy and the end closure for the new fuel are outlined below.

The alloy should be melted again, adjusting the input material to achieve the desired composition more closely. The degree of segregation of nickel and chromium in the braze alloy should be reduced. There are several approaches that could be used to improve the homogeneity of the alloy. The alloy could be prepared through powder metallurgy methods or sputtered onto the fuel surface. Although neither of these methods are very practical from a production standpoint, they could provide valuable information on the alloy. It is essential to know if the $\mathrm{Zr} 2-8 \mathrm{Cr}-8 \mathrm{Ni}$ alloy actually melts at the reported temperature $\left(950^{\circ} \mathrm{C}\right)$ when it is homogenous and of the correct composition.

The current fuel design includes a fusion weld over the brazed joints that serves as a secondary closure. This second closure may not be needed for the new fuel design; but if needed, the effect of welding and recasting the $\mathrm{Zr} 2-8 \mathrm{Cr}-8 \mathrm{Ni}$ alloy should be studied. The corrosion resistance of the $\mathrm{Zr} 2-8 \mathrm{Cr}-8 \mathrm{Ni}$ alloy must be tested at reactor temperature and pressure. Impact testing must be performed on the end closure to simulate reactor handling conditions.

Since no data are available on the tensile strength of the Zr2-8Cr-8Ni alloy, specimens should be machined from the alloy and tensile tests performed. Further studies should be performed to optimize the braze cycle. The influence of temperature and time on the braze characteristics should be examined.

\section{CONCLUSIONS}

The $\mathrm{Zr} 2-8 \mathrm{Cr}-8 \mathrm{Ni}$ alloy was successfully used to obtain an acceptable braze with no voids. This alloy has low neutron capture, excellent wetting and flow properties, and eliminates the cost of handling toxic beryllium. The melting point of the braze alloy was higher than the reported value, probably due to the segregation observed in the SEM studies and also the slight dilution of the alloy to about $7 \mathrm{wt} \% \mathrm{Cr}$ and $7 \mathrm{wt} \% \mathrm{Ni}$. It is postulated that this ternary alloy forms a mock eutectic that mimics the $\mathrm{Ni}-\mathrm{Zr}$ eutectic. If this alloy is in a eutectic region, it is reasonable to assume that a small change in composition would have a marked effect on the melting point. 


\section{REFERENCES}

1: Beal, R. E., and Z.P. Saperstein, "Development of Brazing Filler Metals for Zircaloy," Welding Journal, Vol. 50, No. 7, pp. 275s-291s, July 1971 .

2. Tverberg, J.C., and E. A. Smith, "A Survey of Brazing Alloys for NPR Fuel Elements," HW-67438, September 20, 1960, (Declassified).

3. McCraig, F. D., and R. D. Misch, "Method and Alloy for Bonding to Zirconium," Patent 2,932,887, U.S. Patent Office, April 19, 1960. 